Studia Oecumenica 17 (2017)

DOI: $10.25167 / \mathrm{SOe} / 17 / 2017 / 117-132$

AndRzej Piotr PerzyŃski

Wydział Teologiczny UKSW

\title{
Marriage and Family in Protestant and Evangelical Understanding
}

\begin{abstract}
The sixteenth-century Protestant Reformation was a watershed in the history of the Western theology and law of marriage - a moment and movement that gathered several streams of classical and Catholic legal ideas and institutions, remixed them and revised them in accordance with the new Protestant norms and forms of the day. The Lutheran, Calvinist, and Anglican branches of the Reformation gave birth to three Protestant models of marriage. Like Catholics, Protestants retained the naturalist perspective of marriage as an association created for procreation and mutual protection. They also retained the contractual perspective of marriage as a voluntary association formed by the mutual consent of the couple. Unlike Catholics, however, Protestants rejected the subordination of marriage to celibacy and the celebration of marriage as a sacrament. The Lutheran tradition, from 1517 forward, developed a social model of marriage, grounded in Martin Luther's doctrine of the heavenly and earthly kingdoms. Marriage, Luther and his colleagues taught, was a social estate of the earthly kingdom of creation, not a sacred estate of the heavenly kingdom of redemption. Marriage, John Calvin and his followers taught, was not a sacramental institution of the church, but a covenantal association of the entire community. The Anglican tradition, of the sixteenth and seventeenth centuries, brought forth a commonwealth model of marriage. This model embraced the sacramental, social, and covenantal models inherited from the Continent but went beyond them. Marriage was at once a gracious symbol of the divine, a social unit of the earthly kingdom, and a solemn covenant with one's spouse. Evangelical Christianity understands marriage and the family in light of biblical understanding and Christian experience. Christian marriage and family life is regarded as a sacred and creative calling by all Christians. It is a basic biblical teaching. Marital union in Christ appeals to divine grace for support and fulfillment of a natural union of a man and a woman.
\end{abstract}

Keywords: marriage and family, protestant and evangelical family models, Reformation, Lutheranism, Calvinism, Anglicanism.

\section{Małżeństwo i rodzina $w$ rozumieniu protestanckim i ewangelikalnym}

\section{Streszczenie}

Szesnastowieczna protestancka Reformacja stanowi przełom w historii zachodniej teologii i prawa małżeńskiego - był to moment i ruch, który zebrał kilka strumieni klasycznych i katolickich prawnych koncepcji i instytucji, zmieszał je i odnowił zgodnie z nowymi protestanckimi normami i formami obowiazujacymi w tamtych czasach. Luterańskie, kalwińskie i anglikańskie odłamy Reformacji dały początek trzem protestanckim modelom 
małżeństwa. Podobnie jak katolicy, protestanci utrzymali naturalistyczną perspektywę na małżeństwo jak na związek stworzony dla potrzeb prokreacji i wzajemnej ochrony. Ponadto zachowali kontraktowy aspekt małżeństwa jako dobrowolnego związku zawartego za obopólną zgodą pary. Jednak, w odróżnieniu od katolików, protestanci odrzucili nadrzędność celibatu nad małżeństwem i celebrację małżeństwa jako sakramentu. Od 1517 r. luterańska tradycja rozwinęła społeczny model małżeństwa zakorzeniony w doktrynie Marcina Lutra o ziemskim i niebieskim królestwie. Luter i jego naśladowcy głosili, że małżeństwo jest społeczną instytucją ziemskiego królestwa stworzenia, a nie świętą instytucją niebiańskiego królestwa odkupienia. Jan Kalwin i jego uczniowie uczyli, że małżeństwo nie jest instytucją sakramentalną Kościoła, ale mającym charakter przymierza związkiem całej społeczności. Tradycja anglikańska XVI i XVII w. przedstawiła wspólnotowy model małżeństwa. Obejmował on sakramentalne, społeczne i mające charakter przymierza modele odziedziczone z Europy, a jednocześnie je przekroczył. Małżeństwo stało się pełnym łaski symbolem tego, co boskie, społeczną komórką ziemskiego królestwa i uroczystym przymierzem ze współmałżonkiem. Chrześcijaństwo ewangelikalne widzi małżeństwo i rodzinę w świetle biblijnego rozumienia i doświadczenia chrześcijańskiego. Chrześcijańskie małżeństwo i życie rodzinne są postrzegane jako święte i twórcze powołanie dla wszystkich chrześcijan. Jest to podstawowe nauczanie biblijne. Związek małżeński w Chrystusie odwołuje się do boskiej łaski o wsparcie i dopełnienie naturalnego związku mężczyzny i kobiety.

Słowa kluczowe: małżeństwo i rodzina, protestanckie i ewangelikalne modele rodziny, Reformacja, luteranizm, kalwinizm, anglikanizm.

Love, marriage, and families are subjects of intrinsic interest to nearly everyone. Perhaps this is so because they represent common experiences that are given special favour and protection in one way or another by all societies. Familial activities and relations are intertwined with many other kinds of activities and relations. Accordingly, marriage and family relationships must be understood as part of the cultural life as a whole.

Western perceptions of marriage have largely been shaped by Christianity to the extent that in order to understand what constitutes marriage one must consider Christian views of marriage as they developed over time. Christian ideas of marriage stem from the Old Testament, in particular the book of Genesis, but the Christian understanding of marriage developed within the social and historical context of the Roman Empire (the period when the canon of the New Testament was under construction), and was further clarified during the period of the Middle Ages, when it fell under the direct jurisdiction of the Church. The Reformations of the $16^{\text {th }}$ century brought divergent views of marriage between Catholics and Protestants, and many of the denominational differences in views of marriage persisted, arguably until Vatican II $^{1}$. Today, however, one could argue that Christians have a common view of marriage - indeed, "Christians have more agreement on the nature of marriage than they do on divorce 2 .

${ }^{1}$ Cfr. J. WitTe JR., From Sacrament to Contract: Religion, Marriage, and Law in the Western Tradition, Louisville, KY 1997.

${ }^{2}$ N.L. GeIsLer, Christian Ethics: Issues and Options, Grand Rapids, MI 2010, 299. 


\section{Early Christians' families}

It is the idea that the early Christians' families were not limited by biology. We know that Jesus' message included the claim that his real family was the Christian community, not his mother and his brothers. We know that others noticed that the Christians tians sometimes left their biological families for their new Christian families. And we know that the Christians were often seen as unpatriotic and immoral, as family-wreckers, because they sometimes refused to give in to what was expected of them. However, we also know that Christianity began in households where communities were led by married couples (for example, Prisca and Aquila in Acts 18,18 and 18,25; 1 Cor 16,18; Rom 16,2). These first Christians used family language with reverence in speaking about their own communities, which were not limited by biological ties. According to New Testament scholars, they saw themselves as extended families. This is clear from such evidence as the title of brothers and sisters commonly given to believers, burial in common cemeteries, and conscious modelling of community leadership on that of the household. The vision of church was that of a community that was inclusive of all ${ }^{3}$.

All of this means that family to the first Christians was an expansive term that referenced not just the household, but, more importantly, the community of disciples of Christ. Within this community, some married and lived out the call to discipleship within marriage, while others remained celibate, devoting their lives wholly to the work of the kingdom.

Thus it seems that relationships of love and care that characterize families were not what Jesus was trying to eliminate. Rather, the structure of families, and their preeminence, was problematic, and this is what the first followers of Jesus tried to do something about. They allowed his anti-family sayings to shake them up, and they took pains to cut themselves loose from those family ties that would keep them from being true servants of God. Sometimes this meant leaving one family and embracing another, and sometimes it meant rejecting biological logical family life all together, but either way, the point was to try to live life focused on what really mattered: working to spread the message of Jesus ${ }^{4}$.

${ }^{3}$ Cfr. M. Francis, Marriage in the New Testament Period, in: G.W. Olsen (ed.), Christian Marriage: A Historical Study, New York 2001, 69-70.

${ }^{4}$ Cfr. A.J. Köstengerger, D.W. Jones, God, Marriage, and Family: Rebuilding the Biblical Foundation, Wheaton, IL 2010. 


\section{Protestant models of marriage}

The sixteenth-century Protestant Reformation was a watershed in the history of the Western theology and law of marriage - a moment and movement that gathered several streams of classical and Catholic legal ideas and institutions, remixed them and revised them in accordance with the new Protestant norms and forms of the day, and then redirected them in the governance and service of the Christian West $^{5}$.

\subsection{Medieval Catholic Background}

Prior to the sixteenth century, marriage was principally subject to the theology and law of the Roman Catholic Church. The medieval Church treated marriage and the family in a threefold manner - at once as a natural, contractual, and sacramental unit. First, marriage was a natural association, created by God to enable man and woman to "be fruitful and multiply" and to raise children in the service and love of God. Since the fall into sin, marriage had also become a remedy for lust, a channel to direct one's natural passion to the service of the community and the church. Second, marriage was a contractual unit, formed in its essence by the mutual consent of the parties. This contract prescribed for couples a life-long relation of love, service, and devotion to each other and proscribed unwarranted breach or relaxation of their connubial and parental duties. Third, marriage, when properly contracted and consummated between Christians, rose to the dignity of a sacrament. The temporal union of body, soul, and mind within the marital estate symbolized the eternal union between Christ and His Church, and brought sanctifying grace to the couple, their children, and the church. This sacramental perspective helped to integrate the natural and the contractual dimensions of marriage and to render marriage a central concern of the $\mathrm{church}^{6}$.

Although a sacrament and a sound way of Christian living, however, marriage was not considered to be particularly spiritually edifying. Marriage was a remedy for sin, not a recipe for righteousness. Marital life was considered less commendable than celibate life, propagation less virtuous than contemplation. Clerics, monastics, and other servants of the church were thus to forgo marriage as a condition for ecclesiastical service. Those who could not do so were not worthy of the church's holy orders and offices. Celibacy was something of a litmus test of spiritual discipline and social superiority.

${ }^{5}$ Cfr. M. Parsons, Reformation Marriage. The Husband and Wife Relationship in the Theology of Luther and Calvin, Eugene, OR 2005.

${ }^{6}$ Cfr. J.A. Brundage, Law, Sex, and Christian Society in Medieval Europe, Chicago 1987. 
From the twelfth century forward, the Catholic Church built upon this conceptual foundation a comprehensive canon law of marriage that was enforced by church courts throughout much of Western Christendom. Until the sixteenth century, the canon law of marriage was the law of the West. A civil law or a common law of marriage, where it existed at all, was generally considered supplemental and subordinate. Consistent with the naturalist perspective on marriage, the church's canon law punished contraception and abortion as violations of the created marital functions of propagation and childrearing. It proscribed unnatural relations, such as incest and polygamy, and unnatural acts such as bestiality, buggery, and sodomy. Consistent with the contractual perspective, the canon law ensured voluntary unions by dissolving marriages formed through mistake, duress, fraud, or coercion, and granting husband and wife alike equal rights to enforce conjugal debts that had been voluntarily assumed. Consistent with the sacramental perspective, the church protected the sanctity and sanctifying purpose of marriage by declaring valid marital bonds to be indissoluble, and by dissolving invalid unions between Christians and non-Christians or between parties related by various legal, spiritual, blood, or familial ties. This canon law of marriage, grounded in a rich sacramental theology and ecclesiastical jurisprudence, was formalized and systematized by the Council of Trent in 1563 .

\subsection{Reformation Response}

The Lutheran, Calvinist, and Anglican branches of the Reformation gave birth to three Protestant models of marriage. Like Catholics, Protestants retained the naturalist perspective of marriage as an association created for procreation and mutual protection. They also retained the contractual perspective of marriage as a voluntary association formed by the mutual consent of the couple. Unlike Catholics, however, Protestants rejected the subordination of marriage to celibacy and the celebration of marriage as a sacrament. According to common Protestant lore, the person was too tempted by sinful passion to forgo God's remedy of marriage. The celibate life had no superior virtue and was no prerequisite for ecclesiastical service. It led too easily to concubinage and homosexuality and impeded too often the access and activities of the clerical office. Moreover, marriage was not a sacrament. It was instead an independent social institution ordained by God and equal in dignity and social responsibility with the church, state, and other estates of society. Participation in marriage required no prerequisite faith or purity and conferred no sanctifying grace, as did true sacraments ${ }^{7}$. 1995.

7 Cfr. J.F. Harrington, Reordering Marriage and Society in Reformation Germany, Cambridge 
From this common critique, the Lutheran, Calvinist, and Anglican traditions constructed their own models of marriage. Each Protestant tradition provided a different theological formula for integrating the inherited contractual, natural, and religious perspectives on marriage. Lutherans emphasized the social dimensions of marriage; Calvinists, the covenantal dimensions; and Anglicans, the commonwealth dimensions. Each Protestant tradition also assigned principal legal responsibility for marriage quite differently. Lutherans consigned legal authority mostly to the state, Calvinists to both state and church, and Anglicans mostly to the church. These differences in emphasis and authority among early Protestants were based, in part, on differences among their theological models of marriage ${ }^{8}$.

\subsection{The social dimensions of marriage (Lutheranism)}

The Lutheran tradition, from 1517 forward, developed a social model of marriage, grounded in Martin Luther's doctrine of the heavenly and earthly kingdoms. Marriage, Luther and his colleagues taught, was a social estate of the earthly kingdom of creation, not a sacred estate of the heavenly kingdom of redemption. Though divinely ordained, marriage was directed primarily to human ends, to the fulfilling of civil and spiritual uses in the lives of the individual and of society. Marriage revealed to persons their sin and their need for God's marital gift. It restricted prostitution, promiscuity, and other public sexual sins. It taught love, restraint, and other public virtues. Any fit man and woman were free to enter such unions, clerical and lay alike. Indeed, all persons were encouraged to marry when they came of age, unless they had the rare gift of continence. This was especially imperative for Christian clergy, for a pastor's experience of marriage would enhance his pastoral ministry to the married, and his marital parsonage would serve a model for proper Christian living in the community 9

As part of the earthly kingdom, Lutheran reformers argued, marriage was subject to the civil law of the state, not to the canon law of the church. To be sure, marriage was still subject to God's law, but this law was now to be administered by Christian magistrates who were God's vice-regents in the earthly kingdom. Church officials were required to counsel the magistrate about God's law and to cooperate with him in publicizing and disciplining marriage. All church members, as part of the priesthood of believers, were required to counsel those who contemplated marriage, to admonish those who sought annulment or divorce, and to aid in the rearing of all children as their collective baptismal vows prescribed.

${ }^{8}$ Cfr. K.M. Crowther, Adam and Eve in the Protestant Reformation, New York 2010.

9 Cfr. S. Hendrix, Luther on Marriage, "Lutheran Quarterly" 14 (2000) 3, 335-350. 
But principal legal authority over marriage and family life lay with the state, not with the church.

This new social model of marriage was reflected in the transformation of marriage law in Germany and other Lutheran polities of Western Europe. Civil marriage courts replaced church courts. New civil marriage statutes replaced traditional canon law rules. Lutheran jurists published scores of treatises on marriage law, affirming and embellishing the new Lutheran theology of marriage. The new Lutheran marriage law, like the new Lutheran marriage theology, remained indebted to the Catholic canon law tradition. Traditional marriage laws, like prohibitions against unnatural sexual relations and against infringement of marital functions, remained in effect. Impediments that protected free consent, that implemented biblical prohibitions against marriage of relatives, and that governed the couple's physical relations were largely retained. Such laws were as consistent with the Catholic sacramental model as with the Lutheran social model of marriage.

But changes in marriage theology also yielded changes in marriage law. Because the Lutheran reformers rejected the subordination of marriage to celibacy, they rejected laws that forbade clerical and monastic marriage, that denied remarriage to those who had married a cleric or monastic, and that permitted vows of chastity to annul promises of marriage. Because they rejected the sacramental nature of marriage, the reformers rejected impediments of crime and heresy and prohibitions against divorce in the modern sense. Marriage was for them the community of the couple in the present, not their sacramental union in the life to come. Where that community was broken, for one of a number of specific reasons (such as adultery or desertion), the couple could sue for divorce and the right to remarry. Because persons by their lustful nature were in need of God's remedy of marriage, the reformers removed numerous impediments to marriage not countenanced by Scripture. Because of their emphasis on the Godly responsibility of the prince, the pedagogical role of the church and the family, and the priestly calling of all believers, the reformers insisted that both marriage and divorce be public. The validity of marriage promises depended upon parental consent, witnesses, church consecration and registration, and priestly instruction. Couples who wished to divorce had to announce their intentions in the church and community and to petition a civil judge to dissolve the bond ${ }^{10}$.

${ }^{10}$ Cfr. J. WitTE JR., Law and Protestantism: The Legal Teachings of the Lutheran Reformation, New York 2002. 


\subsection{The Calvinist covenantal model}

The Calvinist tradition, established in mid-sixteenth century Geneva, set out a covenantal model of marriage. This model confirmed many of the Lutheran theological and legal reforms, but cast them in a new ensemble. Marriage, John Calvin and his followers taught, was not a sacramental institution of the church, but a covenantal association of the entire community. A variety of parties participated in the formation of this covenant. The marital parties themselves swore their betrothals and espousals before each other and God - rendering all marriages triparty agreements, with God as third party witness, participant, and judge. The couple's parents, as God's lieutenants for children, gave their consent to the union. Two witnesses, as God's priests to their peers, served as witnesses to the marriage. The minister, holding God's spiritual power of the Word, blessed the couple and admonished them in their spiritual duties. The magistrate, holding God's temporal power of the sword, registered the couple and protected them in their person and property. Each of these parties was considered essential to the legitimacy of the marriage, for they each represented a different dimension of God's involvement in the covenant. To omit any such party was, in effect, to omit God from the marriage covenant ${ }^{11}$.

The covenant of marriage was grounded in the order of creation and governed by the law of God. At creation, God ordained the structure of marriage to be a lifelong union between a fit man and a fit woman of the age of consent. God assigned to this marriage the interlocking purposes of mutual love and support of husband and wife, mutual procreation and nurture of children, and mutual protection of both parties from sexual sin. Thereafter, God set forth, in reason, conscience, and the Bible, a whole series of commandments and counsels for proper adherence to this ideal created structure and purpose of marriage.

God's moral law for the covenant of marriage set out two tracks of marital norms - civil norms, which are common to all persons, and spiritual norms, which are distinctly Christian. This moral law, in turn, gave rise to two tracks of marital morality - a simple morality of duty demanded of all persons regardless of their faith, and a higher morality of aspiration demanded of believers in order to reflect their faith. It was the church's responsibility to teach aspirational spiritual norms for marriage and family life. It was the state's responsibility to enforce mandatory civil norms. This division of responsibility was reflected in sixteenthcentury Geneva in the procedural divisions between the church consistory and the city council. In marriage cases, the consistory was the court of first instance, and would call parties to their higher spiritual duties, backing their recommendations with threats of spiritual discipline. If such spiritual counsel and discipline failed,

${ }^{11}$ Cfr. R.M. KIngdon, Adultery and Divorce in Calvin's Geneva, Cambridge, MA 1995. 
the parties were referred to the city council to compel them, using civil and criminal sanctions, to honour at least their basic civil duties for marriage.

This Calvinist covenantal model mediated both sacramental and contractual understandings of marriage. On the one hand, this covenant model confirmed the sacred and sanctifying qualities of marriage - without ascribing to it sacramental functions. Marriage was regarded as a holy and loving fellowship, a compelling image of the bond between Yahweh and His elect, Christ and His church. But marriage was no sacrament, for it confirmed no divine promise. On the other hand, this covenant model confirmed the contractual and consensual qualities of marriage - without subjecting it to the personal preferences of the parties. Marriage depended for its validity and utility on the voluntary consent of the parties. But marriage was more than a mere contract, for God was a third party to every marriage covenant, and He set its basic terms in the order and law of creation. Freedom of contract in marriage was thus effectively limited to choosing maturely which party to marry - with no real choice about the form, forum, or function of marriage once a fit spouse was chosen.

\subsection{Marriage as a little commonwealth (Anglicanism)}

The Anglican tradition, of the sixteenth and seventeenth centuries, brought forth a commonwealth model of marriage. This model embraced the sacramental, social, and covenantal models inherited from the Continent but went beyond them. Marriage was at once a gracious symbol of the divine, a social unit of the earthly kingdom, and a solemn covenant with one's spouse. But the essential cause, condition, and calling of the family was that it served and symbolized the common good of the couple, the children, the church, and the state all at once. Marriage was appointed by God as "a little commonwealth" to foster the mutual love, service, and security of husband and wife, parent and child. It was likewise appointed by God as a "seedbed and seminary" of the broader commonwealth to teach church, state, and society essential Christian and political norms and habits ${ }^{12}$.

At first, this commonwealth model served to rationalize the traditional hierarchies of husband over wife, parent over child, church over house-hold, state over church. After decades of experimentation, England in the mid-sixteenth century had formally rejected most Protestant legal reforms of marriage introduced on the Continent. It returned to much of the medieval canon law of marriage administered by the church, but now under the supreme headship of the English crown. To call the marital household "a little commonwealth" was to signal its subordinate place

\footnotetext{
${ }^{12}$ Cfr. E.J. Carlson, Marriage and the English Reformation, Oxford 1994.
} 
within the new hierarchy of social institutions of which "the great commonwealth" of England was composed. It was also to call the household to an internal hierarchy of offices that matched the royal and episcopal offices of the great commonwealth. The commonwealth model was thus used to integrate a whole network of parallel domestic and political duties rooted in the Bible and English tradition. Anglican divines and moralists expounded at great length the reciprocal duties of husband and wife, parent and child, master and servant, that would produce a well-ordered little commonwealth. In keeping with the tradition of stability of the great political commonwealth of England, these same Anglican writers prohibited the dissolution of this little domestic commonwealth of the family by divorce.

As the political concept of the English commonwealth was revolutionized and democratized in the seventeenth century, however, so was the English commonwealth model of marriage. The traditional hierarchies of husband over wife, parent over child, and church over family were challenged with a revolutionary new principle of equality. The biblical duties of husband and wife and of parent and child were recast as the natural rights of each household member against the other. The traditional idea of a created natural order of marriage, society, and state met with a new idea of marriage, society, and state formed voluntarily by contracts by individuals in the state of nature. Just as the English commonwealth could be rent asunder by force of arms when it abused the people's natural rights, so the family commonwealth could be put asunder by suits at law when it abused the couple's marital rights. Just as the king could be beheaded for abuses in the commonwealth, so the paterfamilias could be removed from the head of the little commonwealth for abuses in the household. This revolutionary construction of the commonwealth model provided the rationale for the incremental liberalization of English marriage law in the course of the next two centuries. It also provided a stepping stone for the development of a more overtly contractarian model of marriage slowly developed by Enlightenment reformers in the eighteenth and nineteenth centuries ${ }^{13}$.

\section{Evangelical Christianity}

Evangelical Christianity entails being born again (John 3,3) and then experiencing a progressive conformity to the image of God in Christ over the lifespan. Evangelical Christianity understands marriage and the family in light of biblical understanding and Christian experience. It offers a normative vision of family life and relations aimed at embodying Christian convictions in everyday life. The

${ }^{13}$ Cfr. J.T. Johnson, A Society Ordained by God: English Puritan Marriage Doctrine in the First Half of the Seventeenth Century, Nashville, TN 1970. 
family thus bears important theological and ethical significance as an arena where Christian beliefs seek daily expression and where future generations are raised and nurtured.

\subsection{History and Overview}

The origin of the term religion, however, can shed some light on its early history. It lies in two understandings of the Latin verb, religio. It denoted a binding or fastening together and eventually came to indicate a reverence and fear of deity. Religio also denoted a restraining or holding back. While the former points to the reverential aspects of religion, the latter points to the ethical restraint role of religion's bridling of human motives and impulses. Hence, religion is seen etymologically as a force that reconnects human disjointedness, restrains errant impulses, and gives uniqueness, identity, and integrity to the individual.

Evangelical Christianity embodies these characteristics, and its understanding of the family exhibits a wide range of historical influences. From the ancient Jewish tradition, Christianity derives the convictions that sex is a good of creation ordained by God for procreation and pleasure; marriage and the family are human institutions and ordained by God and can be understood as a covenant; and women and men have dignified roles in marriage and family life. In addition to the themes from Hebrew scripture, the writings of the New Testament offer an abundance of thought on marriage and the family. As a result, the use of scripture can vary widely from one interpretation to the next and often depends on views of the authority and function of scripture developed independently from reflection on marriage and family life. Perhaps because it assumes an understanding of the Old Testament or because it is less predicated on the social structure of a single people, the New Testament has much less to say about the family as a sociological unit. Although not denying the value of strong internal ties in a traditional Jewish family (see Luke 1,17), Jesus would not permit such ties to stand in the way of one's decision to follow him (Matt 10,35-36). Genesis 2,24 is cited with approbation twice in the Gospels (Matt 19,5; Mark 10,8) and twice in the Pauline corpus (1 Cor 6,16; Eph 5,31) as indicating the close bonds between husband and wife and, therefore of the family unit. The Greco-Roman tradition influenced Christian thought through its contention that marriage is a secular contract entered by consent of the individuals and dissolvable by legal action and that any felt religious dimension to marriage and family life is a private matter ${ }^{14}$.

${ }^{14}$ Cfr. T.J. ZielińsKI, Protestantyzm ewangelikalny. Studium specyfiki religijnej, Warszawa 2013; N. ModnickA, Małe światy polskiego ewangelikalizmu. Studium z antropologii interpretatywnej, Łódź 2013. 
The history of the church sheds more light on the construction of Christian belief as it relates to marriage and family. Augustine of Hippo, for example, proclaimed the family as a social institution ordained by God that helped to insure three goods: offspring, marital fidelity, and enduring commitment. Augustine's position greatly influenced later thought and is seen to have set the terms, if not the outcome, of theological debate. By the time of the Reformation, four criteria for a valid Christian marriage had emerged: consent, contract, church ceremony, and consummation. These were based chiefly on Augustine's synthesis and the laws and customs of medieval Europe. The foundational impact of the Reformation on the Protestant Christian understanding of marriage and family was to eliminate the requirement of a church ceremony and with it the sacramental (but not the symbolic) character of marriage. Family life was upheld by the Reformers as a secular reality especially blessed by God. From the sixteenth century onward, elements of romantic love involving personal fulfilment and physical pleasure became incorporated into a popular understanding shaping Christian thought to where it began to see the family as a means of self-expression. This became the precursor for modern psychology's influence on religion in general, Protestant Christianity specifically, and its shaping of Christianity's practice and view of marriage and the family.

\subsection{Evangelical Views of Family Relations}

Christian marriage and family life is regarded as a sacred and creative calling by all Christians. It is a basic biblical teaching. Marital union in Christ appeals to divine grace for support and fulfilment of a natural union of a man and a woman. Whereas the Orthodox teaching and practice of marriage is understood in sacramental terms, emphasizing the ecclesial, salvific, and eschatological dimensions of the married life, most Protestants find other expressions and concepts to describe the marital union. Although unwilling to formulate marriage and family life in precisely sacramental terms, Protestants generally stress that this union is a profound spiritual commitment and covenantal relationship. The biblical teaching and the church's participation in assisting the couple to preserve and complete their marriage are held as basic by all Christians. Most Protestants tend to limit the role of the clergy and the church in marriage, as contrasted with the Orthodox teaching, because for them marriage is not constituted by the marriage rite.

Biblical wisdom is paramount to the Evangelical faith in fulfilling God's direction for the family. However, the purpose of the scriptures is not to give a detailed description of the stages of family development or specific instructions for dealing with the diversity of challenges and tasks that face parents and their children. 
Still, there are specific commands and promises given to parents and children in the Bible. Subjects like discipline (Prov 22,6), good communication (Eph 6,4), and familial responsibilities (1 Tim 3,1) are certainly addressed. But it would be a mistake to look at the Christian scriptures as a textbook on family functioning. Lewis Smedes observed that what Protestant Christians generally hold as true is that it would be more helpful to look to the Bible as informing us about human life as a whole, so that we as humans can increasingly understand and evaluate our experiences as people in our nuclear and extended families ${ }^{15}$.

Protestant Christians see the family as a social institution entered into by a private contract that may be blessed by the church. Where explicitly religious dimensions are present, they are thought of as bolstering the couple's private consent. The spiritual foundation for the family is thus by choice and orders the physical, social, and personal foundations of the family covenant with God. Because of this, the Christian family relies heavily on the church and Evangelical community for nurturing family life through its understanding of Scripture, tradition, and experience. The pastoral care provided by the church assists this process by making accessible the social skills and psychological insights helpful to it, and by offering assistance in articulating the theological and cultural context within which a given Christian family seeks to live.

The Christian church is an advocate for the family. There has always been something like what is called the family to protect and nurture those who are young. In modern times, however, there has been an exploration into the ways in which the whole human story might be told in terms of household events. The history of Israel is often carried by family stories. Although the continuity of the church as the New Israel is not dependent on family lineage, the early Christian community is often described in family metaphors. The Bible everywhere assumes the significance of the family. The church has sought throughout its history to establish and maintain the sanctity of the home. It has taught that the family is the vehicle for God's continual creation and rule.

In contemporary times, the evangelical community has strongly supported family values. Although there is some divergence within this segment of the church on specific topics, this generally means that evangelicals share a common worldview - assumptions about the universe, about God, about human beings, about right and wrong, and about lifestyle. This evangelical worldview, for example, is often viewed as anti-divorce, pro-life, anti-gay marriages, and so on; in short, it is a conservative view dedicated to preserving the traditional family. Within this context, the evangelical community promotes family education. Marriage preparation and enrichment as well as childrearing are clear examples

\footnotetext{
15 Cfr. L.B. Smedes, Sex for Christians, Grand Rapids, MI 1976.
} 
of this. The evangelical community prizes opportunities to intentionally sponsor instruction in areas related to strong family values ${ }^{16}$.

Few would argue that the family is not of special concern to the Christian church. For Christians, it was the church that validated marriages and legitimated the birth of children. For most of its history, the church's care for families has centred on landmarks of birth, puberty, marriage, and death as primary modes of care that enable individuals and families to live through the stress that usually accompanies change and loss. Preparing for, sustaining, and nurturing the family in a normative vision, however, is nowhere more apparent than in moments of tragedy in family life. Divorce, abortion, death, adultery, suicide, depression, spouse and child abuse, and a host of other devastating moments in family life are not understandable for Christians apart from a sense of how the Christian faith would have us see and respond to them. In the absence of that vision, Christians lose sight of what the family is about, and thus it and its tragedies are governed by other beliefs and experiences.

The family is an organism of change. Some of that change is unexpected. Some of it is inevitable as individuals within the family grow up and grow older. Because the family is always changing, adaptability is one of its essential characteristics. To believe in a God who is always making something new means that change is an unavoidable dimension of each family structure. Despite wide diversity of form and function throughout human history, the family has fulfilled God's intent to provide a context for creation and care in order to ensure the continuity of humankind. From the perspective of Evangelical Christianity, however, the family can never be an end in itself. In order to be a vital human organism, the family is always moving outside itself for the sake of justice, peace, and freedom in ever widening human communities.

\section{Conclusion}

Marriage law and marriage practices were important issues for many if not most of the Protestant reformers largely because of the intrinsic connection between marriage and family. For them, the family was "the cradle of citizenship," and marriage "stabilized both individuals and society as a whole ${ }^{17}$. Because "traditional marriage law and doctrine did not adequately respect and support the integrity and autonomy of the family or facilitate its social tasks, its reform was

${ }^{16}$ Cfr. G.R. Collins, Family Shock: Keeping Families Strong in the Midst of Earthshaking Change, Wheaton, IL 1995.

17 ST. Ozment, When Fathers Ruled: Family Life in Reformation Europe, Cambridge, MA 1983, p. 8-9. 
an urgent priority ${ }^{18}$. For many Protestant reformers, marriage was a human institution, though one ordained by God, and as such it fell under the jurisdiction of the civil authorities, though they insisted that the secular government was itself instituted by God and thus its laws and rule should be based upon and reflect God's law ${ }^{19}$. Thus, the reformation of marriage was essential for the reform of theology and the development of Christian faith.

From the later sixteenth to the early nineteenth centuries, these Catholic and Protestant models lay at the heart of Western marriage and family life, lore, and law. The medieval Catholic model, confirmed and elaborated by the Council of Trent in 1563, flourished in southern Europe, Spain, Portugal, and France, and their many colonies in Latin and Central America, in the U.S. south and southwest, in Quebec and the Canadian Maritimes, and, eventually, in parts of East and West Africa. A Protestant social model rooted in the Lutheran two-kingdoms theory dominated portions of Germany, Austria, Switzerland, and Scandinavia together with their North American and, later, African colonies.

\section{Bibliography}

Brundage J.A., Law, Sex, and Christian Society in Medieval Europe, Chicago: University of Chicago Press 1987.

Burton L.A. (ed.), Religion and the Family: When God Helps, New York: Haworth Pastoral Press 1992.

CARLson E.J., Marriage and the English Reformation, Oxford: Blackwell 1994.

Collins G.R., Family Shock: Keeping Families Strong in the Midst of Earthshaking Change, Wheaton, IL: Tyndale 1995.

Crowther K.M., Adam and Eve in the Protestant Reformation, New York: Cambridge University Press, 2010.

Cunningham J.L., Scanzoni L.D., Religious and Theological Issues in Family Life Education, in: M.E. Arcus (ed.), Handbook of Family Life Education, Vol. 1, Thousand Oaks, CA 1993.

Francis M., Marriage in the New Testament Period, in: G.W. Olsen (ed.), Christian Marriage: A Historical Study, New York: Herder \& Herder 2001, p. $50-100$.

GeIsler N.L., Christian Ethics: Issues and Options, Grand Rapids, MI: Baker Academic 2010².

18 J. WitTE JR., The Reformation of Marriage Law in Martin Luther's Germany: Its Significance Then and Now, "Journal of Law and Religion" 4 (1986) 2, 296.

19 J. Witte JR., The Reformation of Marriage Law, 313. 
Giblin P.R., Marital Spirituality: A Quantitative Study, "Journal of Religion and Health" 36 (1997), p. 321-332.

Harrington J.F., Reordering Marriage and Society in Reformation Germany, Cambridge: Cambridge University Press 1995.

Hendrix S., Luther on Marriage, "Lutheran Quarterly" 14 (2000) 3, p. 335-350. JASKÓŁA P., Nauka o matżeństwie w Ewangelickim katechizmie dla dorostych, „Studia Teologii Dogmatycznej” (2016) 2, p. 216-230.

Jenkins K.W., Religion and Families, in: S.J. Bahr (ed.), Family Research: A Sixty-Year Review, 1930-1990, Vol. 1, New York: Free Press 1991.

KiJAs Z. (red.), Matżeństwa mieszane, Kraków 2000.

Kingdon R.M., Adultery and Divorce in Calvin's Geneva, Cambridge, MA: 1995. KLESZCZYŃsKi A., Małżeństwo mieszane z punktu widzenia Kościoła Ewangelicko-Metodystycznego, in: Z. KIJAs (red.), Matżeństwa mieszane, Kraków 2000, p. 69-74.

Köstenberger A.J., Jones D.W., God, Marriage, and Family: Rebuilding the Biblical Foundation, Wheaton, IL: Crossway 2010.

Modnicka N., Małe światy polskiego ewangelikalizmu. Studium z antropologii interpretatywnej, Łódź: Wydawnictwo Biblioteka 2013.

Ozment S.E., Ancestors: The Loving Family in Old Europe, Cambridge, MA: Harvard University Press 2001.

Ozment S.E., When Fathers Ruled: Family Life in Reformation Europe, Cambridge, MA: Harvard University Press 1983.

Parsons M., Reformation Marriage. The Husband and Wife Relationship in the Theology of Luther and Calvin, Eugene, OR 2005.

Podzielny J., Wizja matżeństwa w świetle ewangelickiej etyki teologicznej, Opole 2011.

Smedes L.B., Sex for Christians, Grand Rapids, MI: Eerdmans 1976.

Stone L., The Family, Sex, and Marriage in England, 1500-1800, New York: Harper and Row 1979.

Witte J., JR., From Sacrament to Contract: Religion, Marriage, and Law in the Western Tradition, Louisville, KY: Westminster, John Knox Press 1997.

Witte J., JR., Law and Protestantism: The Legal Teachings of the Lutheran Reformation, New York: Cambridge University Press 2002.

WitTE J., JR., The Reformation of Marriage Law in Martin Luther's Germany: Its Significance Then and Now, "Journal of Law and Religion" 4 (1986) 2, p. 293-351.

Zieliński T.J., HucaŁ M., Prawo matżeńskie Kościołów chrześcijańskich w Polsce a forma wyznaniowa zawarcia malżeństwa cywilnego, Warszawa 2016. ZIELIŃSKi T.J., Protestantyzm ewangelikalny. Studium specyfiki religijnej, Warszawa: Wydawnictwo Naukowe ChAT 2013. 